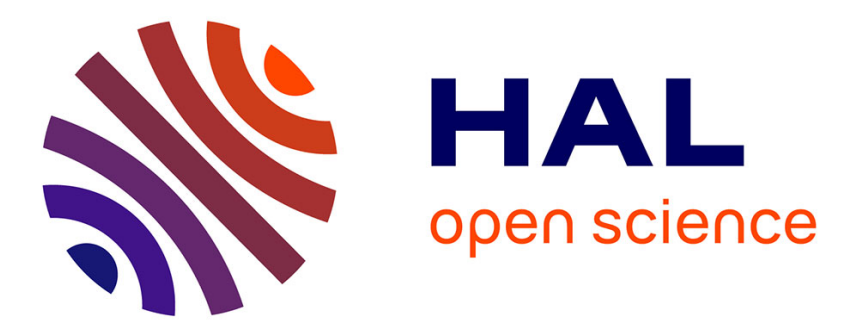

\title{
Accelerated ageing of shales of palaeontological interest: Impact of temperature conditions
}

\author{
Giliane P. Odin, Frederik Vanmeert, Koen Janssens, Hervé P Lelièvre, \\ Jean-Didier P Mertz, Véronique Rouchon
}

\section{> To cite this version:}

Giliane P. Odin, Frederik Vanmeert, Koen Janssens, Hervé P Lelièvre, Jean-Didier P Mertz, et al.. Accelerated ageing of shales of palaeontological interest: Impact of temperature conditions. Annales de Paléontologie, 2014, 100, pp.137 - 149. 10.1016/j.annpal.2013.12.002 . hal-01435164

\author{
HAL Id: hal-01435164 \\ https://hal.science/hal-01435164
}

Submitted on 13 Jan 2017

HAL is a multi-disciplinary open access archive for the deposit and dissemination of scientific research documents, whether they are published or not. The documents may come from teaching and research institutions in France or abroad, or from public or private research centers.
L'archive ouverte pluridisciplinaire HAL, est destinée au dépôt et à la diffusion de documents scientifiques de niveau recherche, publiés ou non, émanant des établissements d'enseignement et de recherche français ou étrangers, des laboratoires publics ou privés. 


\title{
Accelerated ageing of shales of palaeontological interest: Impact of temperature conditions
}

\section{Vieillissement accéléré de schistes argileux d'intérêt paléontologique: impact des conditions de température}

\author{
Giliane P. Odin ${ }^{\mathrm{a}}$, Frederik Vanmeert ${ }^{\mathrm{b}}$, Koen Janssens ${ }^{\mathrm{b}}$, Hervé Lelièvre ${ }^{\mathrm{c}}$, \\ Jean-Didier Mertz ${ }^{\mathrm{d}}$, Véronique Rouchon ${ }^{\mathrm{a}, *}$ \\ a Centre de Recherche sur la Conservation des Collections (Muséum national d'Histoire naturelle, ministère de la Culture et de la Communication, \\ Centre National de la Recherche Scientifique), CRCC, USR3224, CP 21, 36, rue Geoffroy-Saint-Hilaire, 75005 Paris, France \\ ${ }^{\mathrm{b}}$ Department of Chemistry, University of Antwerp, Groenenborgerlaan 171, 2020 Antwerp, Belgium \\ c Centre de Recherche sur la Paléobiodiversité et les Paléoenvironnements (Muséum national d'Histoire naturelle, Centre National de la Recherche \\ Scientifique, Université Pierre-et-Marie-Curie), UMR 7207, CP 38, 8, rue Buffon, 75005 Paris, France \\ ${ }^{\mathrm{d}}$ Laboratoire de Recherche des Monuments Historiques (ministère de la Culture et de la Communication, Centre National de la Recherche Scientifique), \\ LRMH, USR3224, 29, rue de Paris, 77420 Champs-sur-Marne, France
}

\section{A R T I C L E I N F O}

\section{Article history:}

Received 31 January 2013

Accepted 19 June 2013

Available online 24 January 2014

\section{Keywords:}

Shale

Pyrite

Sulfide

Degradation

Fossil

Sulfate

Conservation

\begin{abstract}
A B S T R A C T
The palaeontological collections of the Muséum national d'Histoire naturelle (MNHN, Paris, France) and the Muséum d'Histoire naturelle d'Autun (MHNA, Autun, France) include many fossil specimens originating from the argillaceous shales of the Autun basin (Saône-et-Loire, France). These fossils are preserved within sedimentary rocks containing unstable sulphide compounds, such as pyrite, which may deteriorate in contact with water and oxygen. This alteration provokes crystalline efflorescence and cracks, thus compromising the preservations of the fossils. This work constitutes the first step of a project that aims to understand the mechanisms of alteration of these materials in order to define conservation guidelines for palaeontological collections. For this purpose, eight damaged specimens originating from the Permian Autun basin (Saône-et-Loire, France) were selected and analyzed by X-ray diffraction (XRD), Raman spectroscopy, scanning electron microscopy coupled to energy dispersive X-ray spectrometry (SEM/EDS) and X-ray absorption spectroscopy at the threshold of the sulphur K $\alpha$-edge (XANES). This methodology enabled the characterization of the matrices composition and the chemical nature of the alterations. Subsequently, we have sought to reproduce by artificial ageing the alteration phenomena encountered in the collections. New shale samples were collected on seven outcrops of the same Autun basin. They were analyzed and subjected to artificial ageing at 50\% relative humidity (RH) and at temperatures ranging between $40^{\circ} \mathrm{C}$ and $90^{\circ} \mathrm{C}$. Our work shows that damaged specimens and newly collected shale have a similar mineralogical composition. Yet the crystalline efflorescence material formed on the surface of damaged specimens belongs to the iron sulphate group whereas gypsum predominates on artificially aged shale samples. Reproducing the alterations observed on specimens by artificial ageing remains therefore problematic. Additionally, it appears that the temperature of ageing controls the nature of the damage: at $40^{\circ} \mathrm{C}$, many samples are mechanically damaged whereas no or minor crystalline efflorescence occurs. At $90^{\circ} \mathrm{C}$, it is the opposite tendency that is observed. Finally, mechanical damages do not seem to be correlated with the development of the efflorescence: samples with efflorescent crystals generally do not show clearly visible cracks; those that seem most fragmented do not show any visible efflorescence.
\end{abstract}

(c) 2013 Elsevier Masson SAS. All rights reserved.

\section{R É S U M É}

Les schistes argileux du bassin d'Autun font partie intégrante des collections de paléontologie du Muséum national d'Histoire naturelle (MNHN, Paris, France) et du Muséum d'Histoire naturelle d'Autun (MHNA,

\section{Mots clés :}

Schistes argileux

Pyrite

\footnotetext{
* Corresponding author.

E-mail address: rouchon@mnhn.fr (V. Rouchon).
} 
Sulfure

Dégradation

Sulfate

Conservation
Autun, France). Ces roches sédimentaires contiennent de nombreux fossiles, malheureusement sujets à d'importantes dégradations. En effet, les composés soufrés qu'ils contiennent, en particulier les sulfures de fer tels la pyrite, s'oxydent peu à peu, provoquant des craquelures et des efflorescences cristallines qui compromettent la conservation des fossiles. Ce travail constitue la première étape d'un projet visant à mieux comprendre les mécanismes d'altération des fossiles, afin d'optimiser les conditions propices à leur conservation. Pour cela, nous avons sélectionné, dans les collections patrimoniales, un ensemble de huit spécimens endommagés issus du bassin permien d'Autun (Saône-et-Loire, France) et avons procédé à leur caractérisation à l'aide de différents outils analytiques : diffraction des rayons X (DRX), spectroscopie Raman, microscopie électronique à balayage couplée à une sonde d'analyse élémentaire (MEB/SDE) et spectroscopie d'absorption au seuil de la raie $K \alpha$ du soufre. Des données préliminaires sur la composition des encaissants et la nature des altérations ont ainsi pu être acquises. Par la suite, nous avons cherché à reproduire par vieillissement artificiel les phénomènes d'altération rencontrés dans les collections. Du matériel neuf a ainsi été collecté sur sept affleurements de ce même bassin d'Autun, analysé, puis soumis à des vieillissements artificiels avec une humidité relative de $50 \%$ et à différentes températures. Nos travaux montrent que les schistes des spécimens endommagés et ceux nouvellement prélevés ont une composition minéralogique semblable, mais présentent des efflorescences cristallines sensiblement différentes : elles s'apparentent pour les premiers à des sulfates de fer, et pour les seconds à des sulfates de calcium. La reproduction des mécanismes d'altération par vieillissement artificiel d'un matériel $a$ priori proche des spécimens endommagés reste donc problématique. D’autre part, la température se révèle être un paramètre déterminant du type de la dégradation : à $40^{\circ} \mathrm{C}$, peu d'efflorescences cristallines sont observées mais de nombreuses dégradations mécaniques ont lieu. A $90^{\circ} \mathrm{C}$, c'est la tendance inverse qui est constatée. Enfin, les dégradations mécaniques observées sur les échantillons vieillis artificiellement ne semblent pas corrélées à l'apparition d'efflorescences: les échantillons sur lesquels on observe des efflorescences ne montrent généralement pas de dégradation mécanique évidente à l'œil et ceux qui semblent les plus fragiles ne montrent pas d'efflorescence visible.

(c) 2013 Elsevier Masson SAS. Tous droits réservés.

\section{Introduction}

Shales may contain fossils, as in the case of the world-renowned and widely studied Burgess Shale (Gaines et al., 2012). Although shales of the Autun basin (Saône-et-Loire, France) are less known, they have also delivered a large number of fossils, now stored in various museums, including the Muséum national d'Histoire naturelle, Paris, France (MNHN) and the Muséum d'Histoire naturelle d'Autun, Autun, France (MHNA). Some of these fossils are now showing significant degradations (Rouchon et al., 2012); these are frequently attributed to pyrite breakdown, hence the designation of "pyritized" fossils. However, a great variety of quite unstable sulphide species could as well be suspected to be the origin of this damage.

The alteration of pyritized fossils is mainly due to the oxidation of sulphides (sulphur of oxidation number -I or -II) into sulphates (sulphur of oxidation number $+\mathrm{VI}$ ). Many investigations are currently dedicated to the degradation of sulphide species (Jambor et al., 2000; Vaughan, 2006; Murphy and Strongin, 2009; Chandra and Gerson, 2010; Schoonen et al., 2010; Heidel and Tichomirowa, 2011). It has been in particular shown that the presence of heavy metal impurities (Lehner et al., 2007), microorganisms (Tupikina et al., 2009) or carbonates (Caldeira et al., 2010) significantly influences the oxidation process.

Palaeontologists and museum conservators are well aware of the risks related to pyrite breakdown (Howie, 1977a,b) and consequently developed several preventive and curative methods. Preventive methods, such as dry/anoxic storage in water/airtight plastic bags constitute a promising strategy (Carrio and Stevenson, 2002; McPhail et al., 2003; Day, 2005; Buttler, 2006) but no information is available regarding the acceptable amount of humidity or residual oxygen in the bags. Curative methods, such as the application of ethanolamine thioglycollate (Cornish and Doyle, 1984; Cornish, 1986) are poorly documented with respect to their efficiency and long term side effects. They are moreover invasive and compromise any further diagenesis investigation.

Despite intensive studies dedicated to the decay of iron sulphide, the preservation of palaeontological specimens during their storage in museum collections remains misunderstood (Fellowes and Hagan, 2003). This work constitutes the first step of a project that aims to obtain a better insight into the physicochemical transformations taking place in fossils preserved in shale after their excavation in order to define conservation guidelines for palaeobotanical collections. For this purpose, it appears necessary:

- to characterize the alteration products;

- to reproduce the degradation in laboratory conditions.

Two approaches were therefore developed in this work: firstly, original damaged specimens from the Autun basin (Saône-et-Loire) were analyzed; secondly, shale samples were taken from different outcrops of the same basin and artificially aged with different temperature conditions. The purpose is to compare the newly induced alteration of these shale samples with that formed on the damaged specimens (Rouchon et al., 2012).

\section{Materials and methods}

\subsection{Investigated samples}

\subsubsection{Damaged specimens}

The specimens (Table 1 ) were selected from the MNHN and MHNA collections. While damage is evident (Fig. 1), it is difficult to assess when and under which circumstances it occurred because the history of these specimens is not documented.

The specimens MNHN.F.6888, MNHN.F.6889, MNHN.F.6890, MNHN.F.6891 and MNHN.F.6892 belong to the Flouest collection and were already depicted in the supporting information of a previous study (Rouchon et al., 2012). As these specimens jointly entered the Museum collection in 1865, it is reasonable to assume that they have been subjected to similar conservation conditions. They are now stored in the same drawer, in a room without air conditioning and thus exposed to temperature and humidity fluctuations (Fig. 2).

The specimens MHNA-PAL-000316, MHNA-PAL-000155 and MHNA-PAL-000167 (Fig. 1) were collected in the nineteenth century by Anatole Desplaces de Charmasse and donated to the Société d'Histoire naturelle d'Autun around 1900. In 1964, they were 


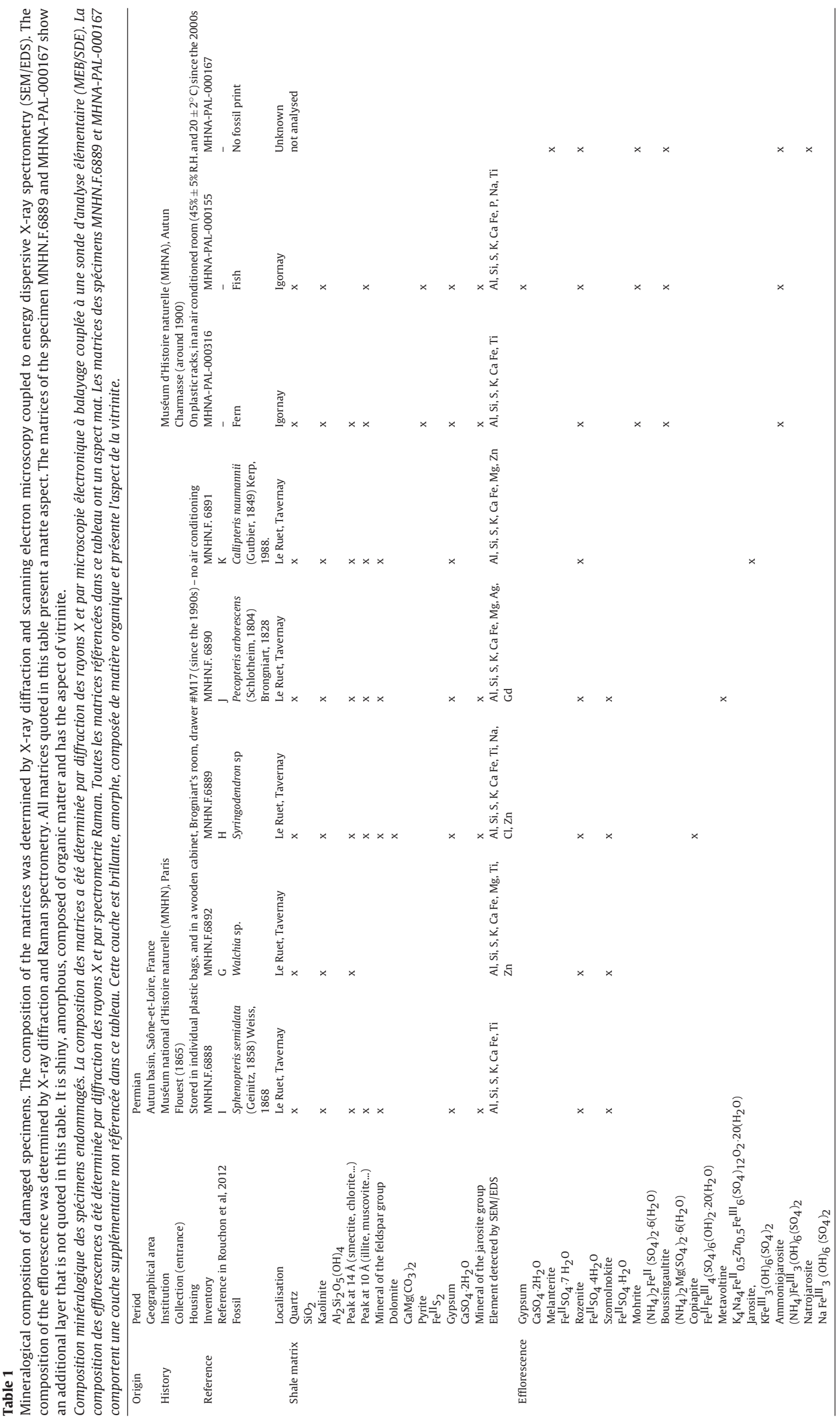



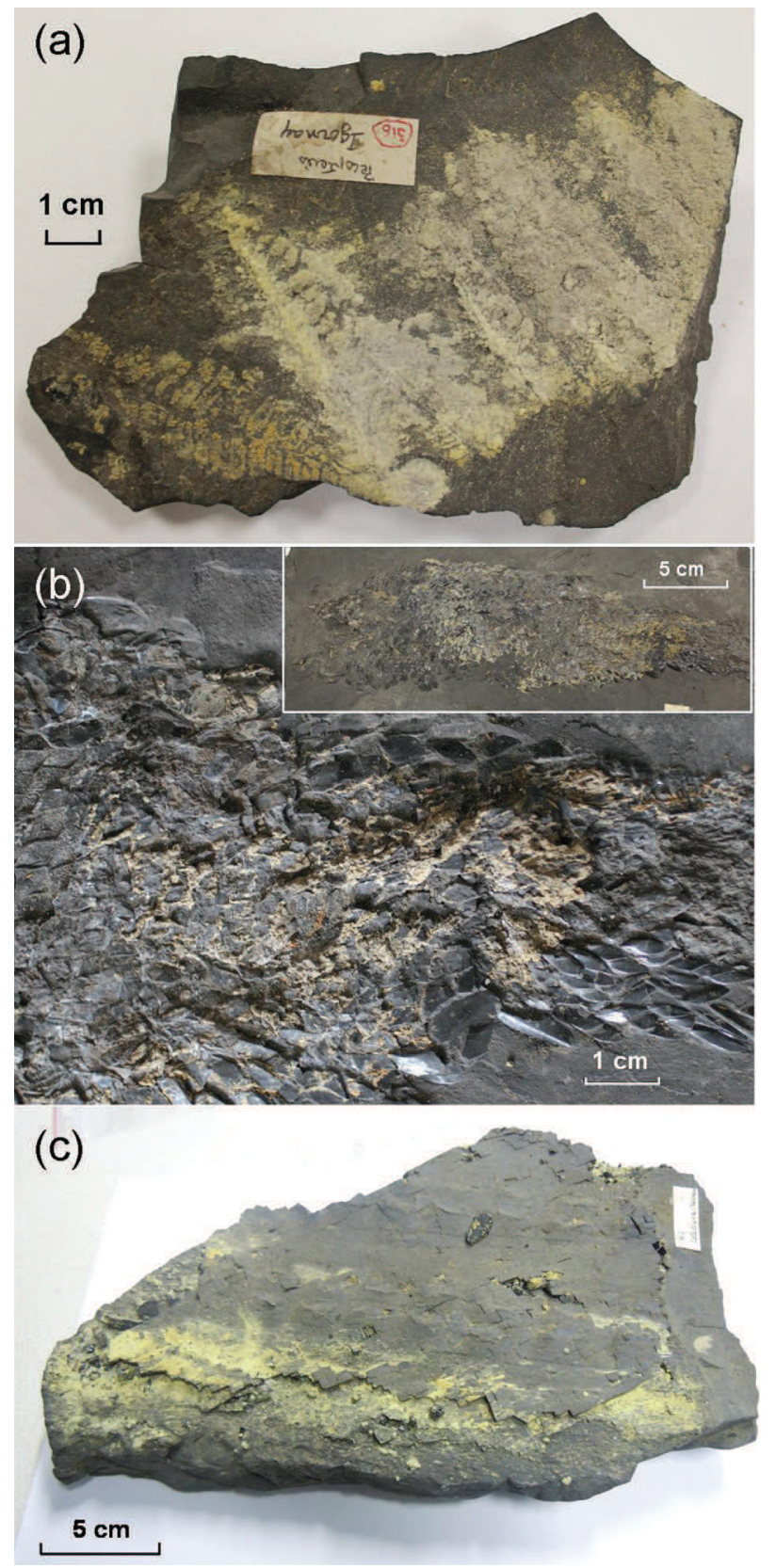

Fig. 1. General view of Muséum d'Histoire naturelle d'Autun (MHNA) specimens. a: MHNA-PAL-000316; b: MHNA-PAL-000155; c: MHNA-PAL-000167. A photographic report of MNHN specimens is available elsewhere.

Vues générales des spécimens du Muséum d'Histoire naturelle d'Autun (MHNA). a: MHNA-PAL-000316; $b$ : MHNA-PAL-000155; $c$ : MHNA-PAL-000167. Un dossier photographique des spécimens du MNHN est disponible par ailleurs.

Rouchon et al., 2012.

donated to the city of Autun and joined the MHNA collection. In 2000 , they moved to an air-conditioned room with stable humidity and temperature conditions (Fig. 2).

Most damaged specimens present a homogeneous matte aspect, but two of them (MNHN.F.6889 and MHNA-PAL-000167) have an additional layer that appears shiny.

\subsubsection{Newly excavated shale samples}

The crystalline efflorescence previously observed on the MNHN specimens was not systematically located on the fossils alone but was also distributed in the shale matrix (Rouchon et al., 2012). It
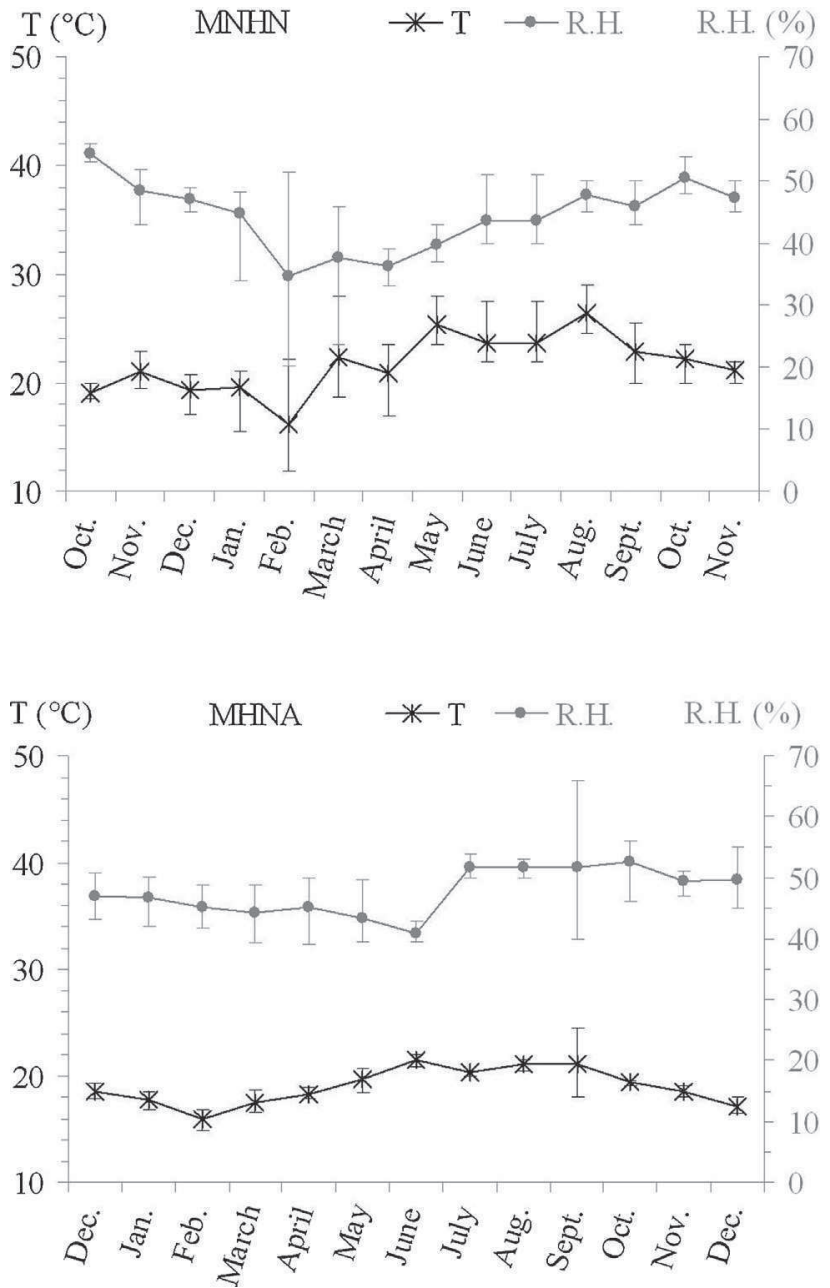

Fig. 2. Temperature and relative humidity of the storage areas. Muséum national d'Histoire naturelle (MNHN), Brongniart's room, \#M17 drawer, between October 2011 and November 2012 (up) and MHNA, air-conditioned vault between December 2011 and December 2012 (down).

Température et humidité relative des lieux de stockage. MNHN, salle Brongniart, tiroir \#M17 entre octobre 2011 et novembre 2012. (en haut) et MHNA, cave climatisée entre décembre 2011 et décembre 2012 (en bas).

was therefore not found necessary to collect shale slabs that contain fossils.

Samples, several decimetres in size, were taken from seven different outcrops of the Autun basin (Table 2). Its stratigraphy is well documented (Elsass Damon, 1977; Châteauneuf et al., 1980; Marteau, 1983). They do not show any visible fossils and present a matte aspect.

As they were taken from outcropping shale layers, the collected slabs might have already been exposed to oxygen and thus subjected to some "primary" oxidation. This oxidation was visible on one sample only, which came from Saint-Léger-du-Bois and presented a few spots of gypsum. Nevertheless, samples were housed in air and watertight plastic bags (ESCAL, Long Life for Art, Germany) with oxygen scavenger bags (ATCO FTM, Long Life for Art, Germany) for 3 months before the study. This conditioning was efficient in limiting drying, but oxygen depletion was sometimes ineffective, probably because the plastic did not withstand piercing from the sharp shale edges. It was also necessary to check regularly the amount of oxygen with an oximeter (Canal 111, Vigaz, Visciano, France).

Some specificity should be noticed: firstly, the slabs originating from the Muse site do not belong to the famous fish layer (Gand 
Table 2

Location of shale material collected for this study.

Localisation des affleurements sur lesquels ont été prélevés les échantillons de schistes argileux.

\begin{tabular}{|c|c|c|c|c|}
\hline \multirow[t]{2}{*}{ Geographical location } & \multicolumn{3}{|l|}{ GPS coordinates } & \multirow[t]{2}{*}{ Autunian stratigraphy } \\
\hline & North & East & Altitude (meter) & \\
\hline Millery $^{\mathrm{a}}$ & $46^{\circ} 59^{\prime} 09,96^{\prime \prime}$ & $4^{\circ} 16^{\prime} 51,27^{\prime \prime}$ & 307 & Millery bedding \\
\hline Surmoulin $^{\mathrm{a}}$ & $47^{\circ} 00^{\prime} 29,14^{\prime \prime}$ & $4^{\circ} 19^{\prime} 21,14^{\prime \prime}$ & 297 & Main layer of the Surmoulin bedding \\
\hline La Comaille $\mathrm{a}^{\mathrm{a}}$ & $46^{\circ} 58^{\prime} 37,75^{\prime \prime}$ & $4^{\circ} 13^{\prime} 50,42^{\prime \prime}$ & 319 & Main layer of the Surmoulin bedding \\
\hline Muse $^{\mathrm{a}}$ & $47^{\circ} 01^{\prime} 36,22^{\prime \prime}$ & $4^{\circ} 22^{\prime} 54,44^{\prime \prime}$ & 322 & Muse bedding \\
\hline Bois-des-Grands-Miens & $47^{\circ} 01^{\prime} 54,15^{\prime \prime}$ & $4^{\circ} 21^{\prime} 50,71^{\prime \prime}$ & 328 & Muse bedding \\
\hline Saint-Léger-du-bois & $47^{\circ} 01^{\prime} 00,34^{\prime \prime}$ & $4^{\circ} 26^{\prime} 54,16^{\prime \prime}$ & 319 & Igornay bedding \\
\hline Igornay & $47^{\circ} 02^{\prime} 58,75^{\prime \prime}$ & $4^{\circ} 22^{\prime} 42,49^{\prime \prime}$ & 327 & Igornay bedding \\
\hline
\end{tabular}

The deposits of La Comaille and Surmoulin correspond to the main layer of Surmoulin (Châteauneuf et al., 1980); the Muséum national d'Histoire naturelle specimens coming from "Le Ruet" probably correspond to this layer.

a Localities of the historical Autunian stratotype.

et al., 2010), but were sampled approx. one to two metres above this layer. Secondly, the outcrop of the site of La Comaille is situated very close to the locality "Le Ruet" where the MNHN specimens were collected. The slabs coming from La Comaille probably correspond to the same layer as the MNHN specimens.

\subsection{Accelerated ageing}

Three sets of newly excavated shale samples were artificially aged at the same level of relative humidity (50\% $\mathrm{RH})$ yet at different temperature values: $40^{\circ} \mathrm{C}, 70^{\circ} \mathrm{C}$ and $90^{\circ} \mathrm{C}$. Ageing was performed in closed vessels with an experimental setup similar to that depicted in the ASTM D6819 standard (Sawoszczuk et al., 2008); however, silica gel was used instead of paper for the monitoring of humidity (PROSorb, Long Life for Art, Germany; pre-conditioned at 50\% $\mathrm{RH}$ ). During ageing, the temperature and humidity conditions were monitored by small sensors placed in the vessel (Hygrobutton, ProgesPlus, USA).

Due to the heterogeneous nature of shale (Berrow and Reaves, 1981; Subasinghe et al., 2009), each slab has been split into eight samples, each approximately 2 to $3 \mathrm{~cm}$ wide and 0.5 to $1 \mathrm{~cm}$ thick. These samples were then dispatched in eight tubes. As a result, each tube contained seven samples, each of them originating from a different outcrop. The eight tubes were closed and placed together in the same oven at a given temperature $\left(40^{\circ} \mathrm{C}, 70^{\circ} \mathrm{C}\right.$ or $\left.90^{\circ} \mathrm{C}\right)$. They were regularly removed from the oven and opened for a few days in order to be photographed. The silica gel was replaced and the tube placed back in the oven to pursue the ageing. In all, 168 samples were artificially aged for a total period of 16 weeks.

\subsection{Characterisation techniques}

\subsubsection{Visual assessment during artificial ageing}

Visible changes during artificial ageing were evaluated for each sample with macro-pictures taken with a digital camera placed on top of a $4300 \mathrm{~K}$ light booth, specifically designed for small samples; see elsewhere for details (Rouchon et al., 2009). The comparison of pictures taken before and during ageing enabled the identification of changes. This visual assessment allowed to pinpoint the most obvious damages.

\subsection{2. $X$-ray diffraction (XRD)}

X-ray diffraction (XRD) was used to identify crystalline phases present in shale specimens and also in newly excavated shales. Small samples, several millimetres large, were taken from the slabs and crushed in an agate mortar. On some samples, XRD was used additionally for the identification of the efflorescence when the latter could be sampled in sufficient quantity. Analyses were conducted with a conventional $\mathrm{Cu}-\mathrm{K}_{\alpha}$ powder diffractometer (D2
Phaser diffractometer) equipped with a Ceramic KFL X-ray tube source and a 1D-linear LynxEye detector, using standard conditions: $30 \mathrm{kV} ; 10 \mathrm{~mA}$; $2 \theta$ range: $3^{\circ}$ to $65^{\circ}$; timescan $0.2 \mathrm{~s}$ step $^{-1}$; 3068 steps; angular speed $200 \mathrm{rad} \mathrm{min}^{-1}$. Phases were identified with the Joint Committee Powder Diffraction Standard using the EVA software (Bruker, Germany).

\subsubsection{Raman spectroscopy (RS)}

Raman spectroscopy (RS) is a powerful tool for the speciation of sulphate minerals and was already used for the analyses of fossil degradation products (Rouchon et al., 2012). When the crystals were present in a quantity too small to be analysed by conventional $\mathrm{XRD}$, they were characterized by RS, by the use of a Raman microscope (inVia, Renishaw, UK; $532 \mathrm{~nm}, 0.5$ to $2.5 \mathrm{~mW}, 50 \times$ objective) following a protocol already described elsewhere (Rouchon et al., 2012). As shale is a highly fluorescent material, the measurements were performed on microsamples taken from the surface of damaged shales.

\subsubsection{Scanning electron microscopy/energy dispersive spectrometer (SEM/EDS)}

Elemental analysis by SEM/EDS was mostly undertaken on shale matrices in order to map elemental distributions on the microscale (with an approximate lateral resolution of 5 micrometers) and to identify correlated elements. In addition, it was useful to characterize more precisely some efflorescence materials such as boussingaultite, mohrite and jarosite type sulfates. Measurements were conducted without any specific sample preparation with a low vacuum scanning electron microscope (JEOL, JSM-5410LV) coupled with an X-ray probe (Oxford Link Pentafet). Elemental mappings were recorded with the following experimental parameters: accelerating voltage, $20 \mathrm{kV}$; pressure, $20 \mathrm{~Pa}$; working distance, $20 \mathrm{~mm}$; aperture, 2; acquisition time, 1 hour. All data were treated with the LinkISIS software (OxFord).

\subsubsection{S K-edge X-ray absorption near edge spectroscopy (XANES)}

XANES appears to be a promising tool for the analysis of sulphur speciation in rocks and minerals (Prietzel et al., 2003; Mikhlin and Tomashevich, 2005; Jugo et al., 2010; Boye et al., 2011). A number of preliminary experiments were also undertaken on the LUCIA beam line of the SOLEIL synchrotron (Saint-Aubin, France) to evaluate the feasibility of XANES for the analysis of sulphur in shale matrices.

The sample was placed in a vacuum chamber $\left(210^{-2} \mathrm{~atm}\right)$ and the measurements were performed in X-ray fluorescence mode with the following geometry: the sample surface was tilted $20^{\circ}$ with respect to the incident beam and the detector was oriented perpendicular to the incident beam. S K-edge XANES spectra were recorded in the energy range from 2440 to $2600 \mathrm{eV}$, employing 175 


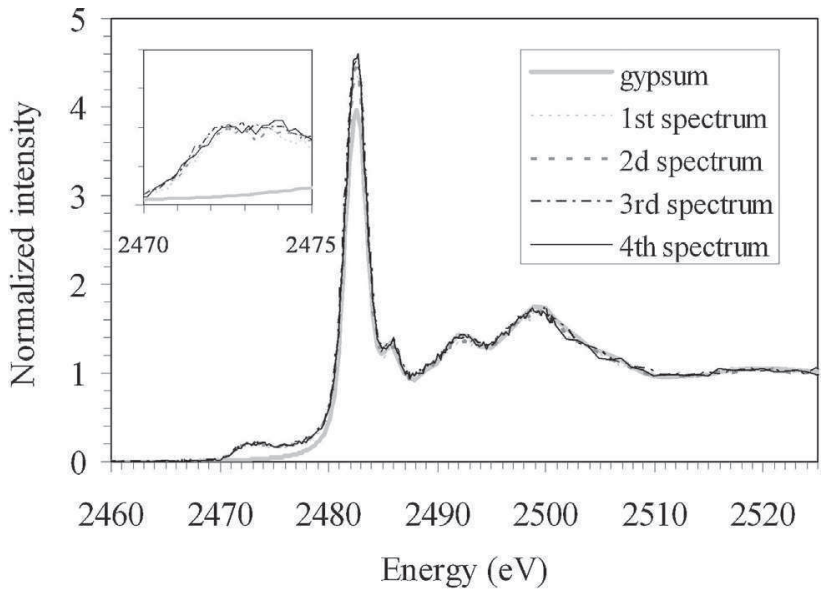

Fig. 3. S K-edge X-ray absorption near edge spectroscopy preliminary testing: evaluation of the stability of samples under the beam. Four spectra were consecutively recorded on the same spot on sample MNHN.F.6889. No modification is observed between the first and the fourth spectra, meaning that the experimental conditions do not provoke sulphur reduction under the beam.

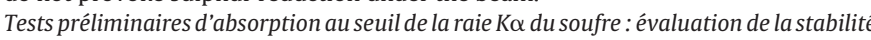
des échantillons sous le faisceau. Les quatre spectres ont été successivement enregistrés sur un même point de l'échantillon MNHN.F.6889. La superposition parfaite des spectres montre qu'il n'y a pas de réduction de soufre sous le faisceau.

data points with a spacing of $0.2 \mathrm{eV}$ between $2465.2 \mathrm{eV}$ and $2500 \mathrm{eV}$ and 65 data points with a spacing of $1 \mathrm{eV}$ elsewhere.

The analysis of sulphur rich species by synchrotron radiation is generally limited by the fact that sulphur is prone to reduction under high intensity light beams, thus leading to measurement artefacts if this reduction occurs during the acquisition (Wilke et al., 2008). On our specimens, this difficulty was overcome by the use of a defocused $1 \times 1 \mathrm{~mm}$ beam that limits the incident light flux per surface unit. As shown on Fig. 3, several consecutive acquisitions could be made on the same position without noticeably changing the spectrum; the latter remains close to that of gypsum $\left(\mathrm{CaSO}_{4} \cdot 2 \mathrm{H}_{2} \mathrm{O}\right)$.
S K-edge XANES measurements were performed on all the matte matrices of the MNHN specimens. Several spectra were recorded on each matrix and the most characteristic spectra were compared to the data collected on sulphur references or available in the literature (Cotte et al., 2006; Bohic et al., 2008; Almkvist et al., 2010) or in databases (ID21, 2011).

\section{Results}

\subsection{Damaged specimens}

\subsubsection{Mineral composition of efflorescence}

The mineral compositions of the efflorescence, as determined by Raman spectrometry, are reported in Table 1. Most efflorescence belongs to the iron sulphate group and more specifically to the ferrous sulphate group (rozenite and szomolnokite are encountered everywhere). Ferric sulphates, such as copiapite, jarosite or metavoltine are also detected in some efflorescence but are present in much lower amounts.

\subsubsection{Mineral composition of matrices}

The mineral compositions of the matrices, as determined by XRD measurements (Fig. 4), are reported in Table 1 . The shiny layers are non-diffracting and are mainly composed of an amorphous organic matter, such as vitrinite, as confirmed by a smear slide. In the shiny layer of MNHN.F.6889, some quartz inclusions of less than 20 micrometers wide are detected by XRD and SEM/EDS.

In contrast, all matte layers are mainly composed of inorganic matter: they contain quartz, kaolinite and several undefined clay minerals (smectite, chlorite, illite, muscovite, etc.) (Table 1). A few samples additionally contain feldspars and carbonates (dolomite). The presence of pyrite is highlighted, but this mineral could be assessed in only two (out of the eight) specimens (Fig. 4) while sulphate alteration phases (gypsum and a mineral of the jarosite group) were identified by XRD in many of the matrices. As the numerous SEM/EDS mappings recorded on the matrices did not evidence the presence of grains rich in sulphur and iron, we

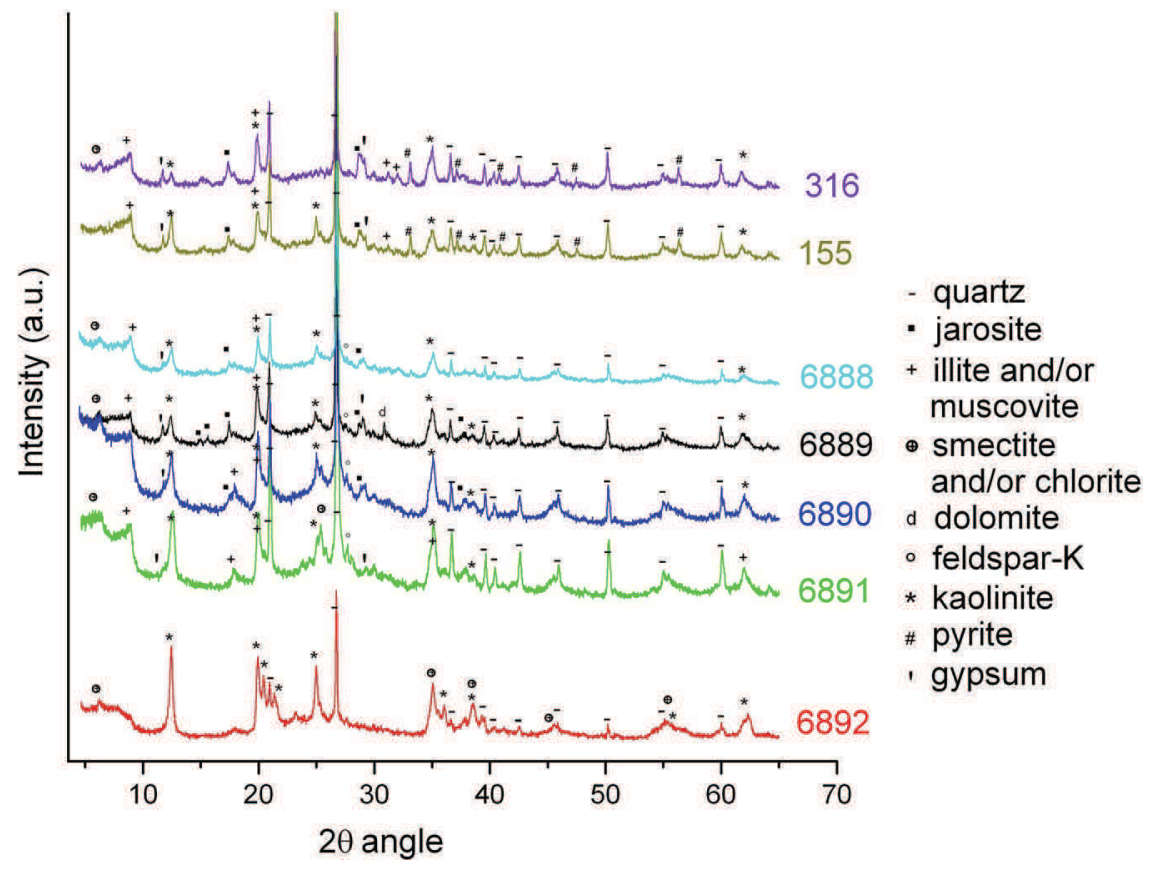

Fig. 4. X-ray diffraction spectra recorded on the specimen matrices. Diffractogrammes enregistrés sur les encaissants des spécimens endommagés 
Table 3

Energy of reference compounds at the maximum of the S K-edge. The composition of minerals was confirmed by X-ray diffraction, with the exception of potassium sulphite, which is a commercial product (Sigma Aldrich ${ }^{\circledR}$ ). The energy calibration was performed on gypsum by fixing the energy of the S K-edge absorption maximum at 2482.5 eV. Energies au maximum du seuil d'absorption de la raie $K$ du soufre mesurées sur des composés de référence. La composition des minéraux a été confirmée par DRX, à l'exception du sulfite de potassium qui est un produit commercial (Aldrich $\left.{ }^{\circledR}\right)$. Les énergies ont été calibrées par rapport à l'énergie du maximum du seuil d'absorption du gypse, fixée à 2482,5 eV.

\begin{tabular}{lll}
\hline Compounds & o.n. of sulphur & Energy at the maximum of the $\mathrm{S} \mathrm{K}$-edge (eV) \\
\hline Gypsum, $\mathrm{CaSO}_{4} \cdot 2 \mathrm{H}_{2} \mathrm{O}$ & $+\mathrm{VI}$ & 2482.5 \\
Anhydrite, $\mathrm{CaSO}_{4} \cdot$ & $+\mathrm{VI}$ & 2482.6 \\
Rozenite, $\mathrm{Fe}^{\mathrm{II}} \mathrm{SO}_{4} \cdot 4 \mathrm{H}_{2} \mathrm{O}$ & $+\mathrm{VI}$ & 2482.7 \\
Melanterite, $\mathrm{Fe}^{\mathrm{II}} \mathrm{SO}_{4} \cdot 7 \mathrm{H}_{2} \mathrm{O}$ & $+\mathrm{VI}$ & 2482.7 \\
$\mathrm{Jarosite}_{\mathrm{KFe}} \mathrm{KFI}_{3}(\mathrm{OH})_{6}\left(\mathrm{SO}_{4}\right)_{2}$ & $+\mathrm{VI}$ & 2482.8 \\
Potassium sulphite, $\mathrm{K}_{2} \mathrm{SO}_{3}$ & $+\mathrm{IV}$ & 2478.2 \\
Marcasite, $\mathrm{Fe}^{\mathrm{II}} \mathrm{S}_{2}$ & $-\mathrm{I}$ & 2472.0 \\
Pyrite, $\mathrm{Fe}^{\mathrm{II}} \mathrm{S}_{2}$ & $-\mathrm{I}$ & 2472.1 \\
Pyrrhotite, $\mathrm{Fe}$ & $-\mathrm{II} \mathrm{II}$ & 2470.3 \\
\hline
\end{tabular}

reasonably suppose that pyrite and jarosite are present in the shape of small crystals less than $5 \mu \mathrm{m}$ large.

\subsubsection{Determination of sulphur speciation in the matrices}

The energies of S K-edge maxima are reported on Table 3 for several reference minerals. As expected, these values show a substantial shift between the most reduced sulphur species (such as pyrrhotite, o.n. - II, $2470.3 \mathrm{eV}$ ) and the most oxidized sulphur species (such as jarosite, o.n. +VI, $2482.8 \mathrm{eV}$ ). The most characteristic spectra recorded on the surface of the different specimen matrices are reported on Fig. 5: all these spectra show a sharp absorption edge positioned at $2482.5 \pm 0.1 \mathrm{eV}$, meaning that sulphur is mostly present as sulphates (o.n. +VI) (Table 3) (ID21, 2011).

In most XANES spectra, a post-absorption edge pattern is noticeable between $2484 \mathrm{eV}$ and $2486 \mathrm{eV}$. As it is present on gypsum/anhydrite spectra and absent from all other sulphate spectra, it is considered to be a signature of calcium sulphate. This observation is consistent with SEM/EDS maps in which 20 to $100 \mu \mathrm{m}$ large grains, rich in calcium and sulphur are detected, mostly next to the surface and sparsely present in the inner part of the matrix. These crystals are not visible with the binocular microscope.

Some of the XANES spectra show no specific feature in the range 2484 to $2486 \mathrm{eV}$ (as spectrum C of Fig. 5a). As XRD evidenced the presence of minerals of the jarosite group, these XANES spectra may reasonably be attributed to iron sulphate.

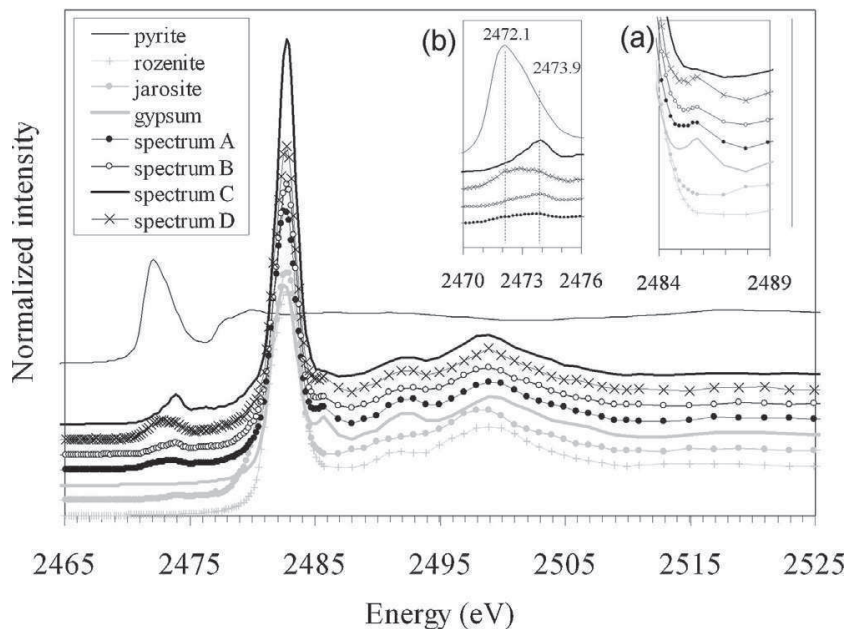

Fig. 5. Example of $\mathrm{X}$-ray absorption near edge spectroscopy spectra recorded on matrices of Muséum national d'Histoire naturelle (MNHN) specimen. Spectra A, B, C and D were respectively recorded on specimen MNHN.F.6888, MNHN.F.6889, MNHN.F.6890 and MNHN.F.6892.

Exemples de spectres XANES enregistrés sur les spécimens du MNHN. Les spectres A, B, C et $D$ ont été respectivement enregistrés sur les spécimens MNHN.F.6888, MNHN.F.6889, MNHN.F.6890 et MNHN.F.6892.
Although sulphur is mostly present as sulphate species, a small XANES pattern in the range 2472 to $2474 \mathrm{eV}$ is noticed for all specimens, attesting the presence of reduced sulphur species (Fig. 5b). This signal seems to be composed of two absorption edges respectively positioned at $2472.1 \mathrm{eV}$ and $2473.9 \mathrm{eV}$. The first edge is similar to that of pyrite or marcasite, i.e., iron sulphides of o.n. -I; it is not possible to distinguish with XANES between these two

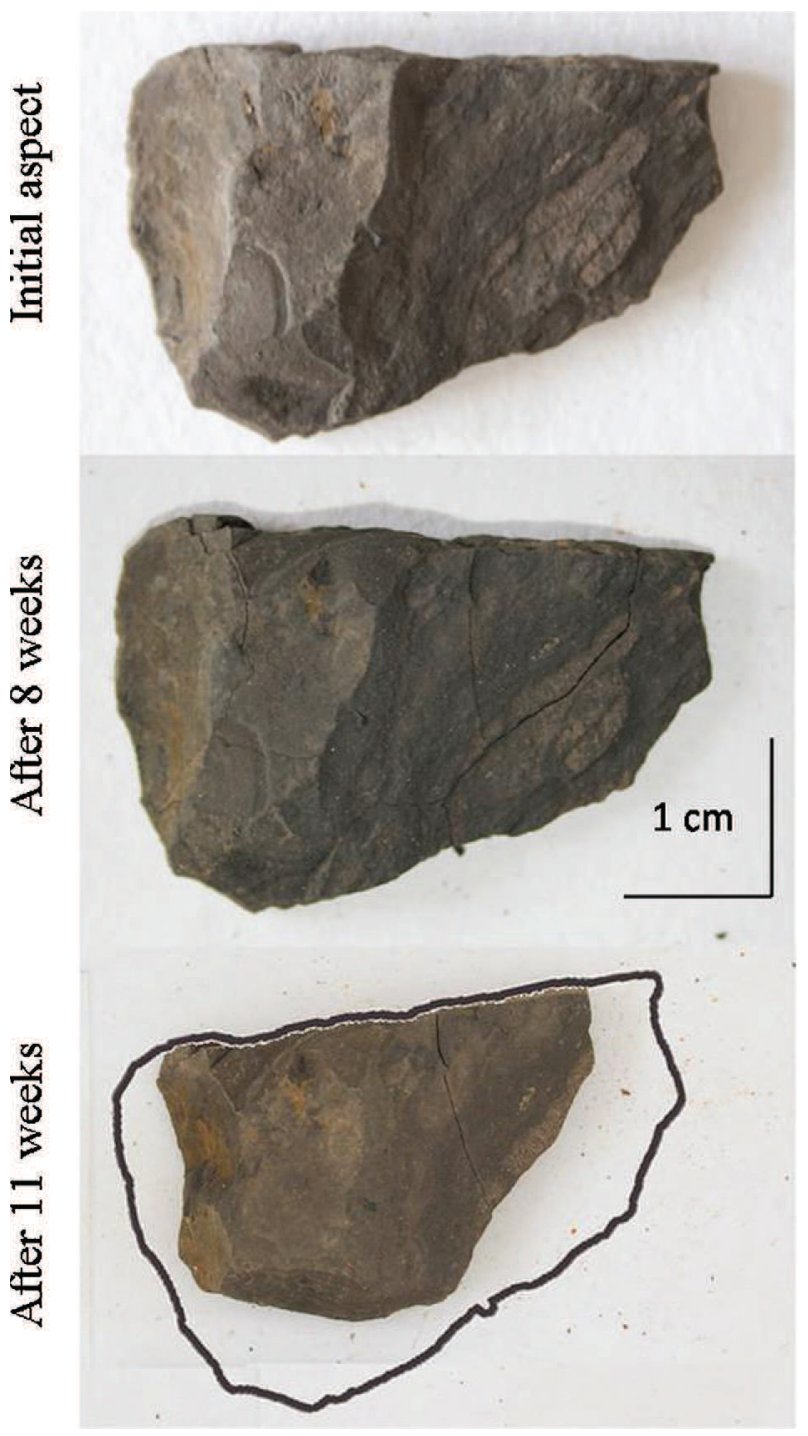

Fig. 6. Apparition of cracks during artificial ageing. Exemple de délitement des schistes après vieillissement artificiel. 
Table 4

List of the different types of damage that are observed on artificially aged shale samples coming from the Surmoulin site. Ageing was performed at 50\% of relative humidity. The week numbers correspond to the first time damage was observed. "No" means that no damage was observed after 16 weeks of artificial ageing.

Liste des différents types de dommages observés après vieillissement artificiel sur les échantillons provenant de Surmoulin. "No " signifie qu'aucun dommage n'est observé après 16 semaines de vieillissement tandis que le nombre de semaine fait référence à la date d'apparition du dommage.

\begin{tabular}{|c|c|c|c|c|c|c|}
\hline \multirow{2}{*}{$\begin{array}{l}\text { Temperature } \\
\text { Type of damage }\end{array}$} & \multicolumn{2}{|l|}{$40^{\circ} \mathrm{C}$} & \multicolumn{2}{|l|}{$70^{\circ} \mathrm{C}$} & \multicolumn{2}{|l|}{$90^{\circ} \mathrm{C}$} \\
\hline & Fissuration & Efflorescence & Fissuration & Efflorescence & Fissuration & Efflorescence \\
\hline Tube 1 & Week 14 & No & Week 8 & No & No & No \\
\hline Tube 2 & Week 7 & No & No & Week 10 & No & Week 10 \\
\hline Tube 3 & Week 9 & No & No & Week 6 & No & Week 6 \\
\hline Tube 4 & No & No & No & Week 8 & No & Week 8 \\
\hline Tube 5 & Week 13 & No & Week 13 & No & No & Week 10 \\
\hline Tube 6 & Week 12 & No & No & Week 15 & No & Week 15 \\
\hline Tube 7 & No & No & No & Week 14 & No & No \\
\hline Tube 8 & No & No & No & Week 16 & No & No \\
\hline
\end{tabular}

minerals because they possess similar signatures. However, as pyrite was detected by XRD (Table 1 ), it seems likely that this first edge is mostly related to pyrite. The second edge does not seem to be related to iron sulphides and remains unattributed.

\subsection{Artificial ageing of newly excavated shales}

\subsubsection{Visual assessment of artificial ageing}

The examination of the photographs before and after ageing made it possible to assess the degradation of samples. Two types of visible damage become apparent: macroscopic crystalline efflorescence and fissuration. Efflorescence initially increases with ageing time and then stabilizes. Fissuration is assessed by the fact that shale slabs split and flake away (Fig. 6).

For each sample, the type of damage and the time when it was becoming visible was documented. This approach shows that all shale samples may get damaged whatever the outcrop they originate from. However, the reactivity of the samples significantly differs from one outcrop to another: the less reactive samples correspond to the sites of Igornay, Millery and Bois-des-Grands-Miens while the most reactive ones originate from the sites of La Comaille, Muse, Saint-Léger-du-Bois and Surmoulin.

Additionally it was noticed that samples of the same origin behave differently from each other even if they are aged in similar temperature conditions. Table 4 summarizes the damages observed on the 24 samples from the Surmoulin site and clearly illustrates the differences among samples: at $40^{\circ} \mathrm{C}$, three (out of the eight) samples appear undamaged after 16 weeks of artificial ageing while two samples already got damaged after less than 10 weeks of ageing.

These observations confirm the necessity to consider a large number of samples for identifying overall tendencies. Despite the discrepancies observed among samples of the same origin, based upon the damage assessment of 168 samples, it is possible to highlight a few general behaviours.

Firstly, no efflorescence is visible on the samples that are showing obvious cracks and vice versa (Table 4 ). This feature is noticeable whatever the origin of the samples. It is clearly illustrated by Table 5 that reports the total number of samples affected by each type of

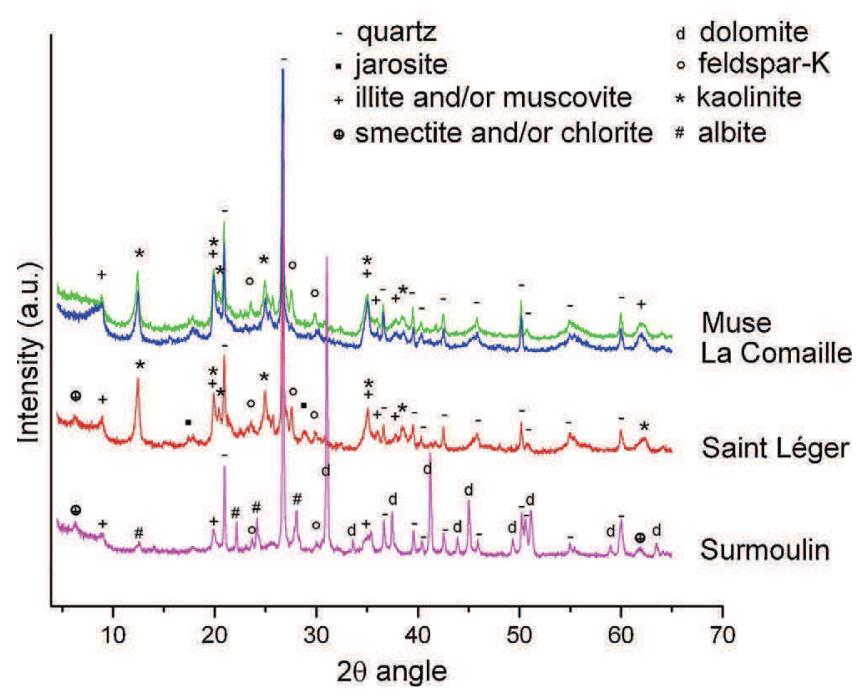

Fig. 7. X-ray diffraction spectra recorded on shale matrices before artificial ageing. Diffractogrammes enregistrés sur les encaissants de schiste avant vieillissement.

damage. In this table, it can be seen that only two samples (out of the 168) simultaneously show efflorescence and cracks. This behaviour appears contrary to our expectations, as one would a priori suppose that the emergence of efflorescence would stress the matrix due to the crystallization pressure during salt growth and make it more fragile.

Secondly, an increase of temperature was expected to enhance all types of damages. This is not the case: at low temperature $\left(40^{\circ} \mathrm{C}\right)$, fissuration prevails whereas at high temperature $\left(90^{\circ} \mathrm{C}\right)$, efflorescence growth prevails (Table 5). The samples from the Surmoulin site (Table 4) illustrate this tendency: at $40^{\circ} \mathrm{C}$, five (out of eight) samples get fissured while no efflorescence appears; at $90^{\circ} \mathrm{C}$, efflorescence is noticeable on five (out of eight) samples whereas none of the samples appear fractured.

Table 5

Summary of the number of newly excavated shale samples that exhibit different types of damage after 16 weeks of artificial ageing. This table takes into account all the shale samples that were collected on the seven outcrops of the Autun Basin (see Table 2).

Résumés des dommages observés après 16 semaines de vieillissement artificiel. Est pris en compte dans ce tableau l'ensemble des prélèvements de schistes argileux réalisés sur les sept affleurements (Tableau 2).

\begin{tabular}{lrrr}
\hline Temperature & $40{ }^{\circ} \mathrm{C}$ & $70{ }^{\circ} \mathrm{C}$ & $90{ }^{\circ} \mathrm{C}$ \\
\hline Fissuration only & 15 & 3 & 1 \\
Efflorescence only & 6 & 1 & 25 \\
Fragmentation and efflorescence & 0 & 25 & 1 \\
No visible damage & 35 & 56 & 31 \\
Total number of samples & 56 & 56 \\
\hline
\end{tabular}


Table 6

Composition of shale samples before artificial ageing as determined by XRD and SEM/EDS.

Composition des schistes argileux avant vieillissement artificiel, déterminée par DRX et MEB/SDE.

\begin{tabular}{|c|c|c|c|c|c|}
\hline Attribution & & Saint Léger & Muse & Surmoulin & Comaille \\
\hline \multirow[t]{8}{*}{ XRD } & Quartz, $\mathrm{SiO}_{2}$ & $\mathrm{x}$ & $\mathrm{x}$ & $\mathrm{x}$ & $\mathrm{x}$ \\
\hline & Kaolinite, $\mathrm{Al}_{2} \mathrm{Si}_{2} \mathrm{O}_{5}(\mathrm{OH})_{4}$ & $\mathrm{x}$ & $\mathrm{x}$ & & $\mathrm{x}$ \\
\hline & Weak peak at $14 \AA$ (smectite, chlorite...) & $\mathrm{x}$ & & $\mathrm{x}$ & \\
\hline & Weak peak at $10 \AA$ (illite, muscovite...) & $x$ & $\mathrm{x}$ & $x$ & $\mathrm{x}$ \\
\hline & Albite, $\mathrm{NaAlSi}_{3} \mathrm{O}_{8}$ & & & $\mathrm{x}$ & \\
\hline & Mineral of the Feldspar group & $\mathrm{x}$ & $\mathrm{x}$ & $\mathrm{x}$ & $\mathrm{x}$ \\
\hline & Dolomite, $\mathrm{CaMg}\left(\mathrm{CO}_{3}\right)_{2}$ & & & $\mathrm{x}$ & \\
\hline & Mineral of the jarosite group & $\mathrm{x}$ & & & \\
\hline \multirow[t]{2}{*}{ SEM/EDS } & Elements detected in all samples & $\mathrm{Al}, \mathrm{Si}, \mathrm{S}, \mathrm{K}, \mathrm{Fe}$ & $\mathrm{Al}, \mathrm{Si}, \mathrm{S}, \mathrm{K}, \mathrm{Fe}$ & $\mathrm{Al}, \mathrm{Si}, \mathrm{S}, \mathrm{K}, \mathrm{Fe}$ & $\mathrm{Al}, \mathrm{Si}, \mathrm{S}, \mathrm{K}, \mathrm{Fe}$ \\
\hline & Other elements & $\mathrm{Mg}, \mathrm{Ti}, \mathrm{Ca}$ & $\mathrm{P}, \mathrm{Ca}, \mathrm{Ti}$ & $\mathrm{Mg}, \mathrm{P}, \mathrm{Ca}$ & - \\
\hline
\end{tabular}

SEM/EDS: scanning electron microscopy coupled to energy dispersive X-ray spectrometry; XRD: X-ray diffraction.

Table 7

Crystalline efflorescence obtained by artificial ageing at $90^{\circ} \mathrm{C}$. Efflorescent crystals were characterized by Raman spectroscopy and (if necessary) SEM/EDS. Efflorescences cristallines obtenues par vieillissement artificiel à $90^{\circ} \mathrm{C}$. Les analyses ont été effectuées par spectroscopie Raman et (au besoin) par MEB/SDE.

\begin{tabular}{llll}
\hline Raman attribution & Saint-Léger-du-bois & Muse & La Comaille \\
\hline Number of samples showing efflorescence at $90^{\circ} \mathrm{C}$ & 5 & 6 & 5 \\
Gypsum, $\mathrm{CaSO}_{4} \cdot 2 \mathrm{H}_{2} \mathrm{O}$ & $\mathrm{x}$ & $\mathrm{x}$ & $\mathrm{x}$ \\
Jarosite, $\mathrm{KFe}^{\mathrm{III}}{ }_{3}(\mathrm{OH})_{6}\left(\mathrm{SO}_{4}\right)_{2}$ & & $\mathrm{x}$ & $\mathrm{x}$ \\
Barite, $\mathrm{BaSO}_{4}$ & & & $\mathrm{x}$ \\
\hline
\end{tabular}

SEM/EDS: scanning electron microscopy coupled to energy dispersive X-ray spectrometry.

\subsubsection{Composition of newly excavated shale before and after ageing}

Analyses were mostly performed on samples coming from the sites of Surmoulin, Saint-Léger-du-Bois, Muse and La Comaille, because they appeared to be the most reactive. The mineralogical composition of the shales, as determined before ageing by XRD (Table 6, Fig. 7), is similar to that of the original specimens. It includes quartz, kaolinite, feldspars and clay minerals. Pyrite is not evidenced although iron and sulphur are detected in all samples by SEM/EDS.

The samples coming from the Surmoulin site are rich in dolomite, which was expected, as the layer of Surmoulin is the only one of the Autun basin that contains significant quantities of carbonates (Elsass Damon, 1977). A minor quantity of jarosite is additionally detected in the samples of the Saint-Léger site despite the fact that:

- no efflorescence is visible;

- these samples were preserved in anoxic conditions of $0.5 \pm 0.2 \%$ $\mathrm{O}_{2}$ until the analysis.

We think that this mineral could already have been present in the inner part of the shale before excavation and was formed during a primary oxidation that occurred on site.

Some of the samples that were mechanically damaged during the ageing at $40^{\circ} \mathrm{C}$ were analysed by XRD. Their diffraction patterns were similar to those of unaged samples. No new crystalline phase was detected consistent with the absence of visible efflorescence.

Table 7 summarises the composition of the crystalline efflorescence that is appearing at $90^{\circ} \mathrm{C}$ : as expected, the efflorescence corresponds to the sulphate group. However, despite the fact that iron was present in all matrices, iron sulphates are found to be minor phases. Only a few crystals of jarosite were found, which were scarcely visible on the macro-pictures. In the samples originating from the La Comaille site, some small crystals of barite, of the order of 10 microns in size, were detected by SEM/EDS (Table 7, Fig. 8a). Beside this minor occurrence of jarosite and barite, all efflorescence crystals appear to be gypsum and show a large variety of crystalline morphologies: thin needles, organised in star shaped structures (Fig. 8a), large parallel beams (Fig. 8b), isolated crystals showing well defined planar edges (Fig. 8c) or conglomerates of crystals of various shapes (Fig. 8d).

\section{Discussion}

\subsection{Characterization of damaged specimens}

Most of the elements detected in the matrices by SEM/EDS are in good agreement with the mineral phases detected by XRD. Silicon and aluminium, the two major elements, mostly correspond to quartz and kaolinite that are the two major mineral phases. These elements can additionally be found in feldspars and other clay minerals (Table 1 , peak at $14 \AA$ and $10 \AA$ ) in combination with magnesium, sodium, potassium, calcium and iron. Sulphur can be related to sulphate or sulphide minerals, such as jarosite or pyrite. Titanium is the only element detected in all samples by SEM/EDS without being attributed to a specific mineral. This may be explained by its ability to substitute silicon in crystalline phases (Hartman, 1969).

This consistency should not conceal the complexity of shale materials, which are composed of organic and inorganic matter and of mineral and amorphous phases. XRD is not the most informative method for the determination of amorphous phases and the elements that are related to a crystalline phase may additionally be present in other amorphous phases. This is typically the case of sulphur and iron. The occurrence of pyrite was demonstrated by XRD only in some specimens. However, iron and sulphur were detected in all matrices by SEM/EDS and a small absorption edge at $2472.1 \mathrm{eV}$, which matches with iron sulphide compounds of o.n. $-\mathrm{I}$, was present in the great majority of the S K-edge XANES spectra. All this information tends to evidence (but does not demonstrate) that there is a small fraction of poorly crystallised iron sulphide still remaining in the matrices, despite the fact that they were excavated more than a century ago.

An additional small absorption edge at $2473.9 \mathrm{eV}$ is suggestive of other sulphide compounds that remain unidentified. These may possibly correspond to zinc sulphides such as sphalerite, showing 


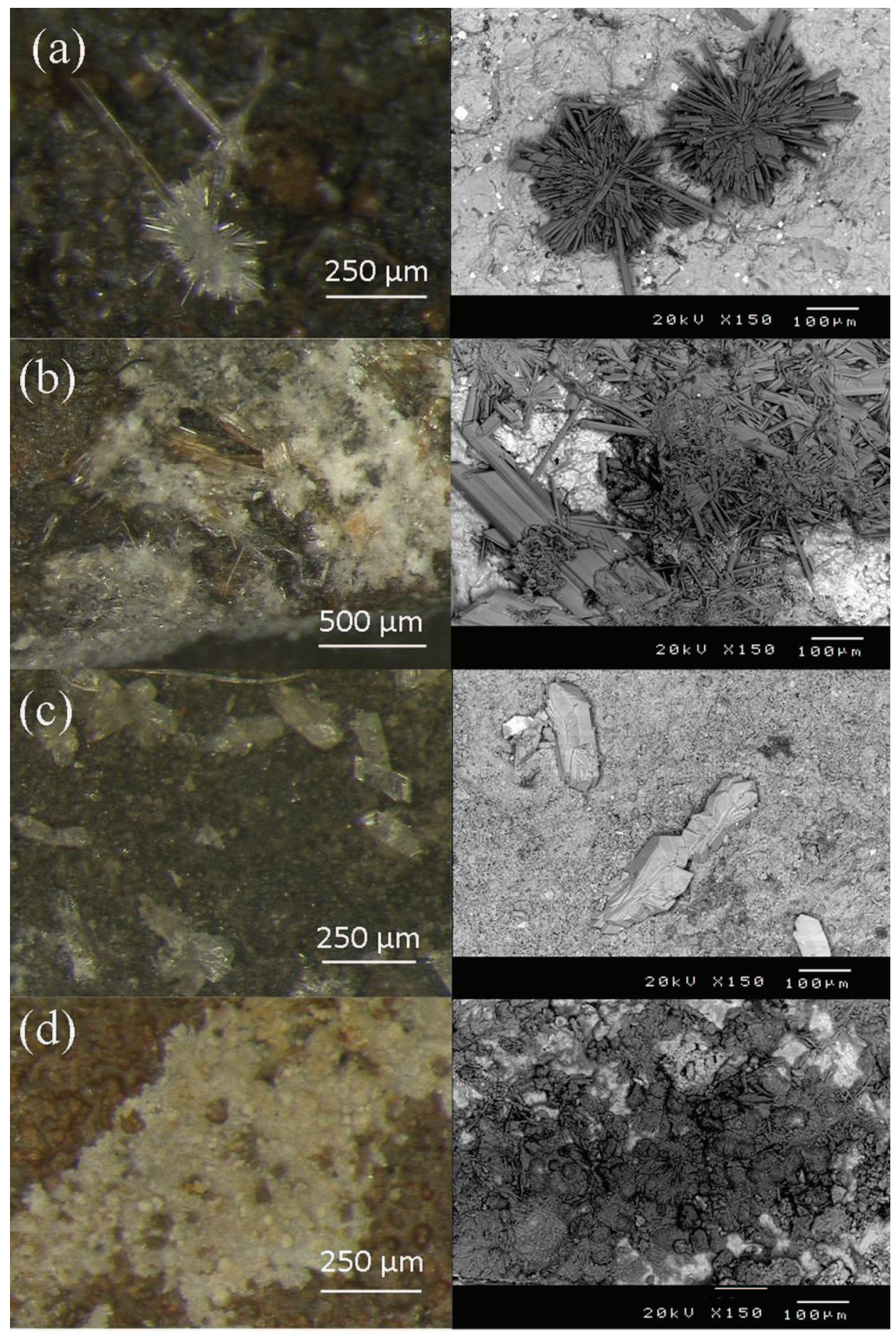

Fig. 8. The different morphologies of gypsum observed on artificially aged shales. Binocular magnifier pictures (left) and scanning electron microscopy backscattered electron mode picture (right). The small white spots observed on Fig. 8-a (right) correspond to barite crystals.

Morphologies des efflorescences de gypse obtenues par vieillissement artificiel. Images obtenues sous loupe binoculaire (à gauche) et par MEB en mode électrons rétrodiffusés (à droite). Les petits points blancs présents sur la Fig. 8-a (à droite) correspondent à des cristaux de baryte.

an absorption edge close to this value (2473.8 eV) (ID21, 2011); available elemental measurements (Elsass Damon, 1977) indicate that the matrices contain traces of zinc $(100 \pm 20 \mathrm{ppm})$. Yet, the presence of sphalerite appears doubtful as:

- our SEM/EDS measurements evidenced small grains of zinc, approx. $10 \mu \mathrm{m}$ in size, that were not associated with sulphur;

- sphalerite was not evidenced by XRD.
This indicates that zinc sulphide (if present) is below the detection limit of XRD and SEM/EDS and is present in a poorly crystallized form.

Other candidates for the attribution of the $2473.9 \mathrm{eV}$ absorption edge (Table 8) can be found among organic sulphides of o.n. -II: thiol, thioether, thiophene or thianthrene exhibit an absorption maximum of the $\mathrm{S}$ K-edge near $2473.9 \mathrm{eV}$ (Bohic et al., 2008; Almkvist et al., 2010), meaning that this energy could be considered as a signature of $\mathrm{C}-\mathrm{S}-\mathrm{C}$ or $\mathrm{C}-\mathrm{S}-\mathrm{H}$ groups. A more quantitative 
Table 8

List of organic and inorganic sulphur compounds showing a S K-edge absorption maximum near $2473.9 \mathrm{eV}$.

Liste des sulfures organiques et inorganiques dont l'énergie au maximum du seuil d'absorption de la raie K du soufre est proche de 2473,9 eV.

\begin{tabular}{|c|c|c|c|c|c|c|}
\hline Type & Compound, formula & $\begin{array}{l}\text { o.n. of } \\
\text { sulphur }\end{array}$ & $\begin{array}{l}\text { S K-edge } \\
\text { maximum (eV) }\end{array}$ & $\begin{array}{l}\text { Calibration } \\
\text { energy }(e V)\end{array}$ & $\begin{array}{l}\text { Compound } \\
\text { used for energy } \\
\text { calibration }\end{array}$ & References \\
\hline Inorganic sulphide & Sphalerite, ZnS & - II & 2473.7 & 2482.5 & Gypsum & ID21, 2011 \\
\hline Thiol & $\begin{array}{l}\text { Glutathion, } \mathrm{C}_{10} \mathrm{H}_{17} \mathrm{~N}_{3} \mathrm{O}_{6} \mathrm{~S} \\
\text { Thiosalicylic acid, 2- } \mathrm{HS}\left(\mathrm{C}_{6} \mathrm{H}_{4}\right) \mathrm{CO}_{2} \mathrm{H} \\
\text { L-cysteine, } \mathrm{HSCH}_{2} \mathrm{CH}\left(\mathrm{NH}_{2}\right) \mathrm{CO}_{2} \mathrm{H} \\
\text { L-Cysteine, } \mathrm{HSCH}_{2} \mathrm{CH}\left(\mathrm{NH}_{2}\right) \mathrm{CO}_{2} \mathrm{H}\end{array}$ & $\begin{array}{l}-\mathrm{II} \\
-\mathrm{II} \\
-\mathrm{II} \\
-\mathrm{II}\end{array}$ & $\begin{array}{l}2473.4 \\
2473.5 \\
2473.4 \\
2473.4\end{array}$ & $\begin{array}{l}2482.5 \\
2482.4 \\
2482.4 \\
2482.5\end{array}$ & $\begin{array}{l}\text { Zinc sulphate } \\
\text { Sulphate, aqueous solution pH } 7 \\
\text { Sulphate, aqueous solution pH } 7 \\
\text { Gypsum }\end{array}$ & $\begin{array}{l}\text { ID21, } 2011 \\
\text { Almkvist et al., } 2010 \\
\text { Almkvist et al., } 2010 \\
\text { Bohic et al., } 2008\end{array}$ \\
\hline Thioether & $\begin{array}{l}\text { Methionine, } \mathrm{H}_{3} \mathrm{CS}\left(\mathrm{CH}_{2}\right)_{2} \mathrm{CH}\left(\mathrm{NH}_{2}\right) \mathrm{CO}_{2} \mathrm{H} \\
\text { Diphenyl sulphide, }\left(\mathrm{H}_{5} \mathrm{C}_{6}\right)_{2} \mathrm{~S} \\
\text { L-Methionine, } \mathrm{H}_{3} \mathrm{CS}\left(\mathrm{CH}_{2}\right)_{2} \mathrm{CH}\left(\mathrm{NH}_{2}\right) \mathrm{CO}_{2} \mathrm{H}\end{array}$ & $\begin{array}{l}-\mathrm{II} \\
-\mathrm{II} \\
-\mathrm{II}\end{array}$ & $\begin{array}{l}2473.4 \\
2473.4 \\
2473.6\end{array}$ & $\begin{array}{l}2482.7 \\
2476.4 \\
2482.4\end{array}$ & $\begin{array}{l}\text { Gypsum } \\
\text { DMSO, } \rho \text {-xylene } \\
\text { Sulphate, aqueous solution } \mathrm{pH} 7\end{array}$ & $\begin{array}{l}\text { Bohic et al., } 2008 \\
\text { Almkvist et al., } 2010 \\
\text { Almkvist et al., } 2010\end{array}$ \\
\hline Thiophene & Dibenzothiophene, $\mathrm{C}_{12} \mathrm{H}_{8} \mathrm{~S}$ & - II & 2474.0 & 2482.7 & Gypsum & Bohic et al., 2008 \\
\hline Thianthrene & Thianthrene, $\left(\mathrm{C}_{6} \mathrm{H}_{4}\right)_{2} \mathrm{~S}_{2}$ & - II & 2474.2 & 2482.7 & Gypsum & Bohic et al., 2008 \\
\hline
\end{tabular}

approach and the use of complementary techniques such as $\mathrm{X}$ ray Photoelectron Spectroscopy might be useful to attribute more precisely the $2473.9 \mathrm{eV}$ absorption edge.

\subsection{Characterization of efflorescence on damaged specimens}

Most efflorescent phases observed on damaged specimens are related to iron sulphates and predominantly iron(II) sulphates. Rozenite is the most abundant of these species, consistent with the fact that the temperature and humidity conditions of the storage (Fig. 2) correspond to its domain of stability (Chou et al., 2002).

Ferric sulphates, such as copiapite, jarosite and metavoltine are often detected together with ferrous sulphates, but in much smaller amounts. The simultaneous occurrence of several iron sulphates raises the question of their paragenesis, i.e. of the sequence of their formation. Iron(II) sulphates are much more abundant than iron(III) sulphates and some specimens (MNHN.F.6888 and MNHN.F.6892) present efflorescent crystals that exclusively belong to the group of iron(II) sulphates. These observations tend to indicate that iron(II) sulphates are the first to form and that iron(III) sulphates are mainly the result of their alteration. These considerations, although hypothetic, are consistent with classical studies of sulphate deposits (Jambor et al., 2000): iron(II) sulphates are often found in the deepest levels of a deposit, which are the most recently altered while iron(III) sulphates are preferentially found near the surface, i.e. in the levels that are the first to be exposed to oxygen and humidity.

The occurrence of a great variety of mixed iron sulphates attests that other cations, such as sodium, potassium and ammonium, play a key role in the crystallization processes. They may have been incorporated as impurities in primary phases of iron(II) sulphates (Jambor et al., 2000), or be present in binary solid solutions. The case of boussingaultite and mohrite, which were simultaneously detected in all MHNA specimens is quite illustrative: these two phases belong to the picromerite group, feature a similar crystal structure and thus show similar diffraction patterns. They are only distinguishable by the fact that mohrite contains $\mathrm{Fe}^{2+}$ that is replaced by $\mathrm{Mg}^{2+}$ in the case of boussingaultite. In our samples, these two phases are thought to occur simultaneously on the micronanoscale as SEM/EDS elemental mapping showed that iron and magnesium were always correlated.

The presence of gypsum was expected since it is one of the most common degradation products found on shales (Mapes and Mapes, 1982) or during the oxidation of sediments that contain sulphide minerals (Jambor et al., 2000). However, it is rarely present in crystal efflorescence and seems to remain in the surface matrix. This may be a thin layer, rich in calcium, initially present when the shale was excavated, or may result from a migration of calcium occurring a posteriori after the excavation.

\subsection{Artificial ageing versus natural ageing}

This work aimed to reproduce the alteration observed on damaged specimens by artificial ageing. This purpose is at least partly achieved since the two main damages observed on the collection specimens, i.e. cracks and efflorescence, could be reproduced on newly excavated shale samples. However, efflorescent crystals produced by artificial ageing are mainly composed of gypsum and differ significantly from those observed on damaged specimen, which are mainly related to iron sulphate.

This discrepancy may in first instance be attributed to the materials themselves. Museum specimens and newly excavated shale samples share similar characteristics, but contrary to museum specimens, the newly excavated shale samples did not include fossils. Additionally, the initial composition of specimens differs slightly from that of newly excavated samples: pyrite for instance was detected in museum specimens but not in newly excavated samples. Does this mean that these samples contain sulphides that are not related to iron sulphide? Complementary measurements, for instance S K-edge XANES spectra, appear to be necessary to estimate the nature and initial amount of sulphides.

Secondly, the discrepancy observed in the different types of efflorescence may possibly be inherent to the ageing conditions themselves. Shale presents a complex structure and its deterioration results from both physical and chemical processes. For example, crystal growth is conditioned by a large number of physico-chemical processes including micro-condensation in the porous matrix, dissolution of ions (e.g. sulphate, iron and calcium), migration of ions, precipitation, evaporation, etc. If a temperature increase provokes additional physical mechanisms, it will be difficult to compare the behaviour of artificially aged new samples with that of original specimens stored in ambient conditions for more than a century.

Whatever the type of efflorescence, the presence and the availability of cations (mainly iron and calcium) appear determinant in crystallization processes. They depend on several parameters, such as the temperature, the $\mathrm{pH}$, the mobility of ions and, the solubility of the crystalline phase. This last parameter is quite low for gypsum $\left(\sim 2 \mathrm{~g} \cdot \mathrm{L}^{-1}\right.$ at $\left.25^{\circ} \mathrm{C}\right)$ and quite high for iron(II) sulphates $\left(\sim 200 \mathrm{~g} \cdot \mathrm{L}^{-1}\right.$ at $20^{\circ} \mathrm{C}$ for melanterite) meaning that the saturation of calcium sulphate solution in pores is easier to achieve than that of iron sulphates.

In micro-porous materials, micro-condensation of water may occur at relative humidity levels that are lower than $100 \%$. This condensation generally follows Kelvin's law and becomes significant when the dimension of the pores is less than $100 \mathrm{~nm}$. The porous structure of shales (porosity: $5 \%$ to $20 \%$ ) includes nanopores of the order of $1 \mathrm{~nm}$ in which water condenses at $50 \% \mathrm{RH}$. This 
condensation is temperature dependent and has a large impact on the dissolution, saturation and precipitation phenomena (Scherer, 2004).

Artificial ageing unexpectedly shows that fissuration is not correlated to the growth of sulphate efflorescence: these two types of deterioration are occurring complementary to each other. At higher temperature, crystal growth predominates, suggesting that ions migrate in the porous media from the inner to the outer part of the shale without provoking strong mechanical stress. Two aspects may explain this behaviour: firstly, according to Kelvin's law, there is less condensation in the material at $90^{\circ} \mathrm{C}$ than at $40^{\circ} \mathrm{C}$. This probably means that there is less mechanical stress in the matrix. Secondly, the transport of ions is favoured at elevated temperature because there is a higher hydrothermal gradient between the inner and the outer part of the shale. The observation of natural rock outcrops contaminated with soluble salts (Winkler, 1997) shows that such a gradient favours ionic transport and crystallisation.

At lower temperature, there is a lower hydrothermal gradient between the inner and the outer part of the samples, leading to a decrease ion mobility. Water vapour sorption may then become the dominant mechanism of alteration, especially when hygroscopic phases such as clay minerals are present. Interestingly, XRD analysis shows a peak at $14 \AA$ (Tables 1 and 6), which is compatible with the presence of chlorite or smectite, two clays that are well known for their ability to swell. Several clayed rock studies dealt with the relationship between reactive clay minerals and their mechanical behaviours (for instance hygric dilation). In these studies the swelling of clays is presented as the result of two mechanisms respectively called "crystalline swelling" and "osmotic swelling" (Norrish, 1954; Madsen and Müller-Vonmoss, 1989). More generally, depending on their nature, their quantity and their porous network, clay minerals are involved in dilation processes that can lead to significant mechanical alteration, such as cracks, peeling and delamination (Scherer and Gonzalez, 2005). This could explain why mechanical damage is mainly observed at $40^{\circ} \mathrm{C}$. However, this hypothesis remains to be confirmed by further investigations. In particular the clay fraction characteristics should be determined and their dilation should be monitored during ageing.

\section{Conclusion}

The first aim of this study was to try and define an analytical methodology for characterizing the alteration of shales. The damage provoked by artificial ageing was assessed by a visual examination of macroscopic photographs. This approach was useful to initiate the project but soon reached its limits. A methodology capable of characterizing and quantifying the mechanical damage of small samples $(2-3 \mathrm{~cm}$ in size) would certainly help future investigations.

In this work, the visual assessment was completed by analytical techniques such as Raman spectroscopy, scanning electron microscopy/energy dispersive spectroscopy and X-ray diffraction. All these complementary techniques were successfully implemented to identify the composition of efflorescence and of shale matrices but an important amount of work remains to be done to develop a quantitative approach.

Additionally, the feasibility of using S-K Edge XANES was explored for sulphur speciation in shale. The analysis of a set of five specimens illustrated its potential for the detection of reduced sulphur compounds. This technique will undoubtedly help to monitor the oxidation of sulphur during artificial ageing and thus give some clues to understand the degradation mechanisms that are occurring at different temperatures.

The second aim of this study was to reproduce shale damage by artificial ageing. This goal was only partially reached, as the crystal growth that was generated on newly collected shale was mainly composed of calcium sulphate (gypsum) whereas the efflorescence found on original specimen mainly consisted of iron sulphate species. Assessing the origin of this discrepancy requires further research. One may suppose that artificial ageing conditions used in this work to provoke efflorescence correspond to a temperature value $\left(90^{\circ} \mathrm{C}\right)$ that is too high to reliably reproduce the damage induced by "natural" ageing conditions. In this respect, a temperature of $40^{\circ} \mathrm{C}$ appears to be more adequate, as it is closer to ambient conditions. However, ageing at this temperature unfortunately provoked no efflorescence. Interestingly, efflorescence and visible mechanical damage appeared not to be correlated, suggesting that the appearance of efflorescence follows a mechanism that does not provoke drastic mechanical stress in the shale.

Artificial ageing conditions are not the only parameters to question. Some other aspects may have an impact on degradation phenomena, such as the history of the damaged specimens, the occurrence of fossil or the presence of active bacteria, etc. These aspects will be considered in the continuation of this work.

\section{Disclosure of interest}

The authors declare that they have no conflicts of interest concerning this article.

\section{Acknowledgement}

This work is part of a PhD that is funded by the Muséum national d'Histoire naturelle, Paris, France and was additionally supported via the S2-ART project (SDD programme of BELSPO, Brussels). The research was realized in partnership with the Palaeontological Collection Management Unit, Collection Department and with the Centre de Recherche sur la Paléodiversité et les Paléoenvironnements (CR2P, CNRS, UMR7207) of the Muséum national d'Histoire naturelle, Paris, France. We are grateful to our colleagues MM. Jean Dejax and Dominique Chabard who provided palaeontological specimens and gave us access to shale deposits and Mrs Marie-Madeleine Blanc-Valleron who was of great help for the interpretation of the XRD data.

Preliminary S-K edge XANES experiments were conducted on the LUCIA beam line of the synchrotron SOLEIL (Saint-Aubin, France) during beam time allocation no. 20110189. We thank MM. Anne-Marie Flanck, Pierre Lagarde and Nicolas Trcera for their availability and their efficient support during this short experiment.

\section{References}

Almkvist, G., Boye, K., Persson, I., 2010. K-edge XANES analysis of sulfur compounds: an investigation of the relative intensities using internal calibration. Journal of Synchrotron Radiation 17, 683-688.

Berrow, M.L., Reaves, G.A., 1981. Trace-elements in scottish soils developed on greywackes and shales - variability in the total contents of basal horizon samples. Geoderma 26 (3), 157-164.

Bohic, S., Murphy, K., Paulus, W., Cloetens, P., Salome, M., Susini, J., Double, K., 2008. Intracellular chemical imaging of the developmental phases of human neuromelanin using synchrotron X-Ray microspectroscopy. Analytical Chemistry 80 (24), 9557-9566

Boye, K., Almkvist, G., Nilsson, S.I., Eriksen, J., Persson, I., 2011. Quantification of chemical sulphur species in bulk soil and organic sulphur fractions by S K-edge XANES spectroscopy. European Journal of Soil Science 62 (6), 874-881.

Buttler, C., 2006. Anoxic storage. In: Buttler, C., Davis, M. (Eds.), Things Fall Apart. Museum Conservation in Practice. National Museum Wales Books, Wales, pp. 32-33.

Caldeira, C.L., Ciminelli, V.S.T., Osseo-Asare, K., 2010. The role of carbonate ions in pyrite oxidation in aqueous systems. Geochimica Cosmochimica Acta 74 (6), 1777-1789.

Carrio, V., Stevenson, S., 2002. Assessment of materials used for anoxic microenvironment. In: Townsend, J.H., Eremin, K., Adriaens, A. (Eds.), Conservation Science. Archetype, Edinburgh, pp. 32-38.

Chandra, A.P., Gerson, A.R., 2010. The mechanisms of pyrite oxidation and leaching: a fundamental perspective. Surface Science Reports 65 (9), 293-315. 
Châteauneuf, J.J., Farjanel, G., Feys, R., Marteau, P., 1980. Sondages stratigraphiques dans le bassin d'Autun: étude préliminaire. Bulletin trimestriel de la Société d'Histoire Naturelle et des Amis du Musée d'Autun 95, 61-83.

Chou, I.M., Seal, R.R., Hemingway, B.S., 2002. Determination of melanterite-rozenite and chalcanthite-bonattite equilibria by humidity measurements at $0.1 \mathrm{MPa}$. American Mineralogist 87 (1), 108-114.

Cornish, L., 1986. The treatment of decaying pyritiferous fossil material using ethanolamine thioglycollate. Geological Curator 4 (7), 451-454.

Cornish, L., Doyle, A.M., 1984. Use of ethanolamine thioglycollate in the conservation of pyritized fossils. Paleontology 27 (2), 421-424.

Cotte, M., Susini, J., Metrich, N., Moscato, A., Gratziu, C., Bertagnini, A., Pagano, M., 2006. Blackening of Pompeian cinnabar paintings: X-ray microspectroscopy analysis. Analytical Chemistry 78 (21), 7484-7492.

Day, J., 2005. Practical application of the Revolutionary Preservation (RP) system for marcasite. In: Verger, I. (Ed.), ICOM CC Meeting, Volume 1. James \& James, The Hague, pp. 435-442.

Elsass Damon, F., (Thèse) 1977. Les « schistes bitumineux » du bassin d'Autun : pétrographie, minéralogie, cristallochimie, pyrolise. Université Pierre et Marie Curie, Paris, 93 p. (inédit)

Fellowes, D., Hagan, P., 2003. Pyrite oxidation: the conservation of historic shipwrecks and geological and palaeontological specimens. Reviews in Conservation 4, 26-38.

Gaines, R.R., Hammarlund, E.U., Hou, X., Qi, C., Gabbott, S.E., Zhao, Y., Peng, J., Canfield, D.E., 2012. Mechanism for Burgess shale-type preservation. Proceedings of the National Academy of Sciences of the United States of America 109 (14), 5180-5184.

Gand, G., Steyer, J.S., Chabard, D., 2010. Re-activation of palaeontological fieldworks in the famous locality of Muse, autunian, lower permian of the autun basin (Burgundy, France). Report 2010 and futur future plans. Bourgogne Nature 12, $10-28$.

Hartman, P., 1969. Can $\mathrm{Ti}^{4+}$ replace $\mathrm{Si}^{4+}$ in silicates. Mineralogical Magazine 37 (287), 366-369.

Heidel, C., Tichomirowa, M., 2011. The isotopic composition of sulfate from anaerobic and low oxygen pyrite oxidation experiments with ferric iron - new insights into oxidation mechanisms. Chemical Geology 281 (3/4), 305-316.

Howie, F.M.P., 1977a. Pyrite and conservation, part 1: historical aspects. Geological Curators Group Newsletter 9, 457-465.

Howie, F.M.P., 1977b. Pyrite and conservation, part 2. Geological Curators Group Newsletter 10, 497-512.

ID21, 2011. ID21 Sulfur XANES spectra database home. European Synchrotron Radiation Facility (http://www.esrf.eu/UsersAndScience/Experiments/Imaging/ ID21/php).

Jambor, J.L., Nordstrom, D.K., Alpers, C.N., 2000. Metal-sulfate salts from sulfide mineral oxidation. In: Jambor, J.L., Nordstrom, D.K., Alpers, C.N. (Eds.), Sulfate Minerals: Crystallography, Geochemistry and Environmental Significance. Reviews in Mineralogy and Geochemistry, Volume 40. Mineralogical Society of America, Geochemical Society, Washington DC, pp. 303-350.

Jugo, P.J., Wilke, M., Botcharnikov, R.E., 2010. Sulfur K-edge XANES analysis of natural and synthetic basaltic glasses: implications for s speciation and s content as function of oxygen fugacity. Geochimica Et Cosmochimica Acta 74 (20), 5926-5938.
Lehner, S., Savage, K., Ciobanu, M., Cliffel, D.E., 2007. The effect of As, Co and Ni impurities on pyrite oxidation kinetics: An electrochemical study of synthetic pyrite. Geochimica Et Cosmochimica Acta 71 (10), 2491-2509.

Madsen, F.T., Müller-Vonmoss, V., 1989. The swelling behaviour of clays. Applied Clay Science 4 (2), 143-156.

Mapes, R.H., Mapes, G., 1982. Removal of gypsum from microfossiliferous shales. Micropaleontology 28 (2), 218-219.

Marteau, P., (Thèse) 1983. Le bassin permo-carbonifère d'Autun : stratigraphie, sédimentologie et aspects structuraux. Université de Dijon, France, 188 p. (inédit)

McPhail, D., Lam, E., Doyle, A., 2003. The heat sealing of Escal barrier films. The Conservator 27, 107-116.

Mikhlin, Y., Tomashevich, Y., 2005. Pristine and reacted surfaces of pyrrhotite and arsenopyrite as studied by X-ray absorption near edge structure spectroscopy. Physics and Chemistry of Minerals 32 (1), 19-27.

Murphy, R., Strongin, D.R., 2009. Surface reactivity of pyrite and related sulfides. Surface Science Reports 64 (1), 1-45

Norrish, K., 1954. The Swelling of Montmorillonite. Faraday Society Discussion 18, 120-134.

Prietzel, J., Thieme, J., Neuhausler, U., Susini, J., Kogel-Knabner, I., 2003. Speciation of sulphur in soils and soil particles by X-ray spectromicroscopy. European Journal of Soil Science 54 (2), 423-433.

Rouchon, V., Badet, H., Belhadj, O., Bonnerot, O., Lavédrine, B., Michard, J.G., Miska, S., 2012. Raman and FTIR spectroscopy applied to the conservation report of paleontological collections: identification of raman and FTIR signatures of several iron sulfate species such as ferrinatrite and sideronatrite. Journal of Raman Spectroscopy 43, 1265-1274.

Rouchon, V., Durocher, B., Pellizzi, E., Stordiau-Pallot, J., 2009. The water sensitivity of iron gall ink and its risk assessment. Studies in Conservation 54 (4), 236-254.

Sawoszczuk, T., Baranski, A., Lagan, J.M., Lojewski, T., Zieba, K., 2008. On the use of ASTM closed vessel tests in accelerated ageing research. Journal of Cultural Heritage 9 (4), 401-411.

Scherer, G.W., 2004. Stress from crystallization of salt. Cement Concrete Research $34,1613-1624$.

Scherer, G.W., Gonzalez, J.I., 2005. Characterization of swelling in clay-bearing stone. In: Turkington, A. V. (Ed), Stone decay in the architectural environment. Geological Society of America, special paper 390, 51-61.

Schoonen, M.A.A., Harrington, A.D., Laffers, R., Strongin, D.R., 2010. Role of hydrogen peroxide and hydroxyl radical in pyrite oxidation by molecular oxygen. Geochimica Et Cosmochimica Acta 74 (17), 4971-4987.

Subasinghe, N.D., Awaja, F., Bhargava, S.K., 2009. Variation of kerogen content and mineralogy in some Australian tertiary oil shales. Fuel 88 (2), 335-339.

Tupikina, O.V., Rassulov, V.A., Kondrat'eva, T.F., 2009. Patterns of pyrite oxidation by different microorganisms. Microbiology 78 (2), 165-169.

Vaughan, D.J. (Ed.), 2006. Sulfide mineralogy and geochemistry. Reviews in Mineralogy and Geochemistry, Volume 61. Geochemical Society and Mineralogical society of America, Washington DC, $714 \mathrm{p}$.

Wilke, M., Jugo, P.J., Klimm, K., Susini, J., Botcharnikov, R., Kohn, S.C., Janousch, M., 2008. The origin of $\mathrm{S}^{4+}$ detected in silicate glasses by XANES. American Mineralogist 93 (1), 235-240.

Winkler, E.M., 1997. Stone in Architecture: Properties, Durability, Third edition. Springer Verlag, Berlin, Heidelberg, 311 p. 